\title{
PERTUMBUHAN SAGU (Metroxylon sp) DI HUTAN ALAM PAPUA
}

\author{
Batseba A. Suripatty ${ }^{1,2}$, Erny Poedjirahajoe ${ }^{3}$, Satyawan Pudyatmoko $^{3}$ dan $_{\text {Budiadi }}{ }^{3}$ \\ ${ }^{1}$ Balai Penelitian Kehutanan Manokwari, Inamberi, Manokwari. \\ ${ }^{2}$ Program Doktor Ilmu Kehutanan Fakultas Kehutanan Universitas Gadjah Mada \\ ${ }^{3}$ Fakultas Kehutanan Universitas Gadjah Mada, Jalan Bulaksumur, Yogyakarta, 55281 \\ Korespodensi Email : 'bettysuripatty@gmail.com
}

Diterima : 10 Juli 2016 Disetujui : 15 September 2016

\begin{abstract}
Intisari
Tanaman sagu (Metroxylon sp) merupakan jenis tanaman palma yang tumbuh di sekitar rawa dan lahan tergenang air di daerah tropis. Tanaman sagu tumbuh pada lahan berlumpur dengan kuantitas air yang sangat bervariasi mulai dari lahan kering sampai lahan tergenang tetap. Makin lama penggenangan lahan, pertumbuhan tanaman muda (tunas/semai) sangat pesat, tetapi pertumbuhan pada tingkat tanaman pohon sangat lambat. Tujuan penelitian mengetahui hubungan pertumbuhann sagu (Metroxylon sp klimatik (kelembaban, suhu, cahaya) dan biotik (tanaman atau vegetasi lain). Hasil penelitian menunjukkan bahwa Hubungan pertumbuhan sagu dengan faktor lingkungan edafik (air), klimatik (kelembaban, cahaya), dan biotik (vegetasi) dihasilkan bahwa secara umum air mempunyai pengaruh terhadap pertumbuhan sagu sedangkan faktor kelembaban untuk semua tipetempat tumbuh yakni pada daerah tergenang, daerah temporer dan daerah kering tidak mempengaruhi pertumbuhan sagu.
\end{abstract}

Kata Kunci : Biotik, Edafik, Klimatik, Papua, Pertumbuhan, Sagu

\begin{abstract}
Sago plants (Metroxylon sp) is a type of palm tree that grows around swamps and waterlogged land in the tropics. Sago palms grow on muddy land, with the quantity of water varies greatly, ranging from dry land to land remained logged. The longer the land $\square$ ooded, the growth of young plants (shoots / seedling) very rapidly, but the growth of the trees are very slow. This study aims to determine the relationship of the growth of sago (Metroxylon sp) with climatic factors (humidity, temperature, light) and biotic (plants or other vegetation). The results showed that the relationship of growth of sago with environmental factors, edaphic (water), climatic (humidity, light) and biotic factors (vegetation) are generally water has an in $\square$ uence on the growth of sago while the humidity factor for all types of places to grow, that is, the area stagnant water, temporary areas and dry areas do not affect the growth of sago.
\end{abstract}

Kata Kunci : Biotic, Climatic, Edafik, Growth, Papua

\section{PENDAHULUAN}

Sagu tumbuh di daerah berrawa yang berair tawar atau daerah rawa yang bergambut dan daerah sepanjang aliran sungai, sekitar sumber air atau dihutan-hutan rawa yang kadar garamnya (salinitas) tidak terlalu tinggi. Manan dkk (1984). Lingkungan yang baik untuk pertumbuhan sagu adalah daerah yang berlumpur, dimana akar napas tidak terendam, kaya mineral dan bahan organik air tanah berwarna cokelat dan bereaksi agak asam (Harsanto, 1986). Habitat yang demikian cocok untuk pertumbuhan mikroorganisme yang sangat berguna bagi pertumbuhan tanaman sagu. Apabila akar napas sagu terendam terus-menerus, maka pertumbuhan sagu akan terhambat, sehingga pembentukan aci atau karbohidrat dalam batang juga terhambat. 
Tumbuhan sagu tumbuh dengan baik pada kondisi lingkungan dengan kelembaban nisbi udara $60 \%$ dan pertumbuhan akan terhambat apabila kelembaban nisbi udara kurang dari $45 \%$, sedangkan suhu udara berkisar antara $24^{\circ}-30^{\circ} \mathrm{C}$ (Harsanto, 1986). Sagu toleran terhadap salinitas sedang (Flach, 1983). Pertumbuhan sagu yang ideal membutuhkan curah hujan 2000 - 4000 m secara merata sepanjang tahun, cahaya penuh, $\mathrm{pH}$ minimum 4 dan keadaan lingkungan dengan genangan air secara reguler tetapi tidak terus menerus (Flach 1977). Sagu dapat tumbuh pada tanah-tanah organik, akan tetapi sagu yang tumbuh pada kondisi tanah yang demikian menunjukan gejala defisiensi terhadap beberapa unsur hara tertentu yang ditandai dengan berkurangnya jumlah daun dan umur sagu lebih panjang yaitu dapat mencapai 15-17 tahun (Haryanto dan Pangloli, 1992).

Daerah penyebaran sagu di Papua meliputi Merauke, Timika, Nabire, Yapen, Waropen, Sarmi, Sentani, dan Biak, sedangkan di Papua Barat meliputi Sorong, Teminabuan, Bintuni, Wasiordan Babo (Anonim, 1976).Penyebaran sagu di daerah-daerah tersebut meliputi daerah-daerah sepanjang aliran sungai. Kondisi penyebaran tersebut mengakibatkan terbentuknya tempat tumbuh antara lain tempat tumbuh daerah rawa yaitu daerah yang tergenang air terus menerus, tempat tumbuh daerah transisi yaitu daerah yang tergenang air tidak terus-menerus dan tempat tumbuh daerah kering yaitu daerah yang tidak tergenang air. Suryana (2007) menyatakan bahwa tumbuhan sagu mempunyai daya adaptasi yang tinggi pada daerah rawa-rawa dan lahan marginal yang tidak memungkinkan pertumbuhan bagi tanaman pangan dan tanaman perkebunan, sehingga sagu dapat berperan sebagai tanaman konservasi.
Batang tumbuhan sagu terbentuk setelah masa russet berakhir yaitu setelah berumur sekitar 3-4 tahun, dan kemudian membesar dan memanjang dalam waktu sekitar 54 bulan (Flach 2005 dalam Barahima 2005). Batang sagu berbentuk silinder atau bulat memanjang dengan diameter sekitar 50$60 \mathrm{~cm}$, bahkan dapat mencapai $80-90 \mathrm{~cm}$. Pada umumnya diameter batang bagian bawah lebih besar dibandingkan dengan diameter batang bagian atas. Tumbuhan sagu memiliki batang tertinggi apabila telah sampai pada umur panen yakni 11 tahun atau lebih. Pada masa itu tinggi pohon sagu telah mencapai 13-16 m, tetapi ada pula yang dapat mencapai $20 \mathrm{~m}$ dengan bobot sekitar satu ton (Haryanto dan Pangloli, 1992). Variasi tinggi batang sagu sangat tergantung pada jenis dan pengaruh kondisi lingkungan tumbuh. Pada kondisi lingkungan tumbuh yang baik, dalam arti tanahnya subur, kandungan air cukup, maka batang sagu memiliki ukuran yang lebih tinggi dibandingkan dengan kondisi lingkungan yang kurang baik. Batang tumbuhan sagu terdiri dari lapisan kulit bagian luar yang keras berupa lapisan epidermal, dan bagian dalam berupa empulur yang mengandung serat-serat dan pati. Tujuan penelitian untuk melihat hubungan pertumbuhan sagu dengan air, cahaya, kelembaban, vegetasi, curah hujan, suhu dan tanah.

\section{METODE PENELITIAN}

\section{Lokasi dan Waktu Penelitian}

Penelitian dilaksanakan di hutan alam Seget, Kabupaten Sorong Provinsi Papua Barat dan hutan alam Kainui, Kabupaten Yapen Provinsi Papua pada bulan November 2014 - April 2015. Dapat ditempuh dengan jalan darat yaitu sekitar $250 \mathrm{~km}$ dalam waktu 4 jam dan dari serui ke kainui dapat ditempuh dengan jalan darat sepanjang $60 \mathrm{~km}$ 


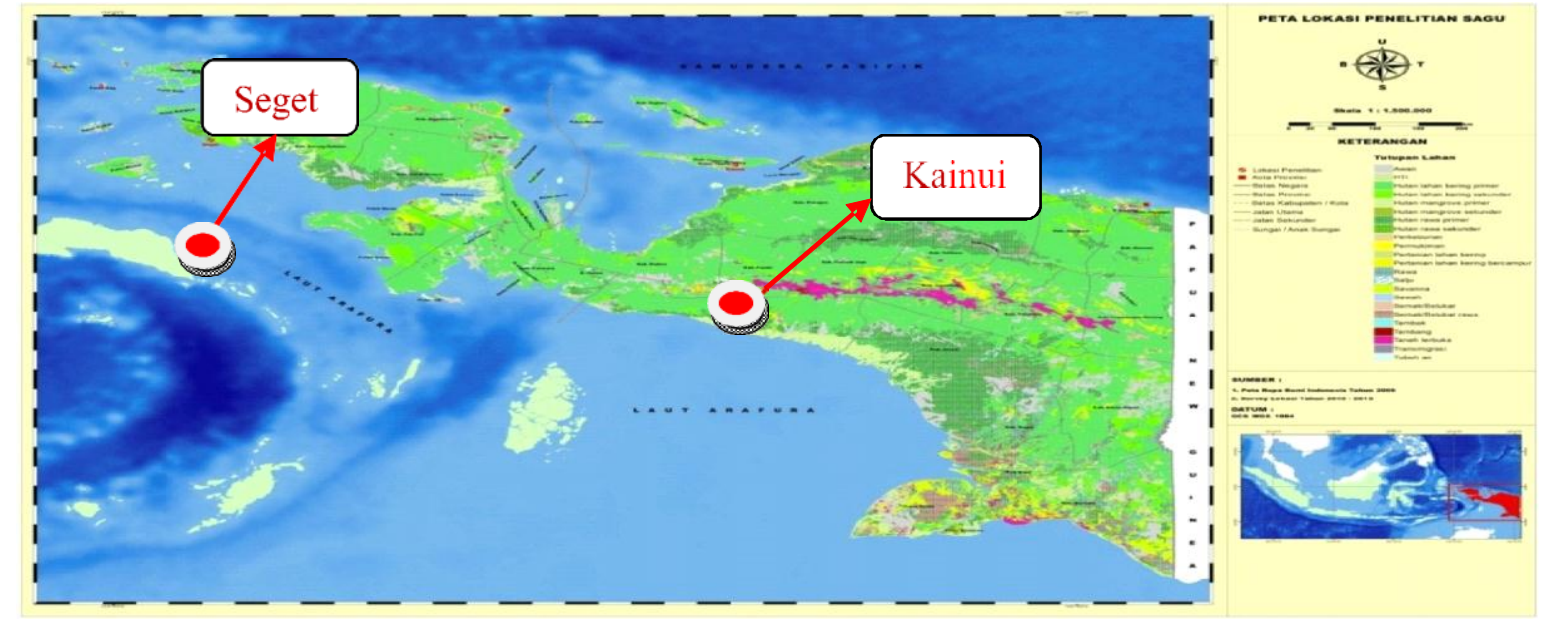

Gambar 1. Peta Lokasi Penelitian di Seget, Kabupaten Sorong Papua Barat dan Kainui, Kabupaten Yapen Papua.

Tabel 1. Informasi Letak Geografis Populasi Sagu.

\begin{tabular}{|c|c|c|c|c|c|c|}
\hline Populasi & Kabupaten & Penutupan Lahan & Koordinat & Jenis Tanah & $\begin{array}{c}\text { Lereng } \\
(\%)\end{array}$ & $\begin{array}{l}\text { Elevasi } \\
(\mathrm{m} \mathrm{dpl})\end{array}$ \\
\hline Seget & Sorong & Hutan pimer & $\begin{array}{l}1^{\circ} 24^{\prime} 0^{\prime \prime} \mathrm{LS}- \\
130^{\circ} 58^{\prime} 0^{\prime \prime} \mathrm{BT}\end{array}$ & $\begin{array}{l}\text { PodsolikMerah } \\
\text { Kuning }\end{array}$ & $<3$ & $100-2800$ \\
\hline Kainui & Yapen & Hutan pimer & $\begin{array}{l}1^{\circ} 26^{\prime} 0^{\prime \prime} \mathrm{LS}- \\
131^{\circ} 1^{\prime \prime} \mathrm{BT}\end{array}$ & $\begin{array}{c}\text { Podsolik Merah } \\
\text { Kuning }\end{array}$ & $<2$ & $0-100$ \\
\hline
\end{tabular}

\section{Prosedur Pengumpulan Data}

\section{Hubungan Pertumbuhan Sagu dengan Faktor Lingkungan Porositas tanah, pH air kelembaban, cahaya, vegetasi}

\section{Pengamatan Faktor Lingkungan}

\section{a. Sifat fisik tanah}

Pada setiap wilayah sampel diambil tiga sampel untuk setiap tipe habitat, sehingga jumlah sampel yang digunakan untuk keperluan analisis adalah 6 sampel. Sifat fisika tanah yang diamati dalam penelitian ini meliputi porositas. Analisisnya dilakukan di laboratorium departemen Ilmu Tanah dan Sumberdaya Lahan Fakultas Pertanian IPB Bogor.

\section{b. Sifat air}

Sampel air diambil dari habitat, yang tergenang temporer air tawar (T2AT), dan tergenang permanen (TPN). Sampel air diambil dari bagian permukaan, bagian tengah, dan bagian bawah dan dicatat per ketinggian. Pada setiap petak sampel diambil tiga sampel secara diagonal, sama seperti pengambilan sampel tanah. Sampel dari tipe habitat yang sama kemudian dicampur untuk selanjutnya diambil tiga sampel pada setiap tipe habitat. Dengan demikian, maka jumlah sampel secara keseluruhan dari tiga wilayah sampel, tiga tipe habitat, dan tiga sampel dari masing-masing habitat adalah sebanyak : $3 \times 2=6$ sampel air.

Pengukuran variabel berkaitan dengan sifat air dilakukan di lapangan dan di laboratorium yaitu:

$\mathrm{pH}$, ditetapkan dengan menggunakan $\mathrm{pH}$ meter air.

Analisis sifat airdilakukan di Laboratorium Penguji Balai Pengkajian Bioteknolgi Badan Pengkajian dan Penerapan Teknologi (BPPT) Serpong.

\section{c. Iklim}

Data yang dikumpulkan adalah temperatur udara, kelembaban udara relatif, curah hujan, hari hujan, rata-rata suhu udara maksimum dan minimum, yang dipperoleh dari di kantor BMKG Kota Sorong dan BMKG Kota Yapen.

Data iklim lokal ini diperoleh dari dua stasiun Klimatologi yaitu stasiun Klimatologi 
Sorong, dan Yapen. Semua data iklim, tanah, dan kualitas air rawa dari wilayah sampel dikompilasi untuk memperoleh data rata - rata. Data rataan untuk menjelaskan kondisi iklim mikro, tanah, dan kualitas air rawa dalam komunitas sagu alami di Papua dan Papua Barat.

\section{d. Pengamatan Vegetasi}

Pengamatan vegetasi lain yang tumbuh bersama-sama dengan tanaman sagu dalam jalur pengamatan pada tingkat semai hingga tingkat pohon, sehingga diperoleh informasi jenis tumbuhan yang berasosiasi dengan sagu.

2. Hubungan Pertumbuhan Sagu dengan Faktor Lingkungan Porositas Tanah, pH Air, Kelembaban, Cahaya, Vegetasi

\section{Analisis Regresi Linier Berganda}

Dalam penelitian ini menggunakan analisis regresi berganda karena jumlah variabel independen yang digunakan lebih dari satu variabel. Sugiyono (2005) perumusan dari regresi linier berganda adalah sebagai berikut:

$$
\mathrm{Y}=\mathrm{a}+\mathrm{b} \mathrm{X}+\mathrm{b} \mathrm{X}+\mathrm{b} \mathrm{X}+\mathrm{b} \mathrm{X}+\mathrm{b} 5 \mathrm{X} 5+\mathrm{E}
$$

Keterangan:

$\mathrm{Y}=$ Pertumbuhan Tegakan Sagu

$\mathrm{a}=$ konstanta

$\mathrm{b}=$ Koefisien Regresi Variabel X (Porositas tanah)

$\mathrm{b}_{\text {a }}=$ Koefisien Regresi Variabel X (pH air)

$\mathrm{b}_{3}=$ Koefisien Regresi Variabel $\mathrm{X}_{3}$ (Kelembaban)

$\mathrm{b}_{4}=$ Koefisien Regresi Variabel $\mathrm{X}_{4}$ (Cahaya)

b5 = Vegetasi

$\mathrm{E}=$ Error

\section{HASIL DAN PEMBAHASAN}

Faktor lingkungan $\mathrm{pH}$ air, cahaya, dan vegetasi mempengaruhi pertumbuhan sagu jenis sagu wafok, pada daerah tergenang, daerah temporer dan daerah kering, sedangkan kelembaban tidak mempengaruhi pertumbuhan sagu.

Untuk lokasi Seget, air dan cahaya mempengaruhi pertumbuhansagujenisWahnan, padadaerahtergenang dan temporer sedangkan kelembaban dan vegetasi tidak mempengaruhi. Untuk daerah tergenang air dan cahaya mempengaruhi pertumbuhan sagu, sedangkan kelembaban dan vegetasi tidak berpengaruh. Air dan cahaya mempengaruhi pertumbuhan sagu wirere pada daerah tergenang dan daerah temporer, sedangkan kelembaban dan vegetasi tidak memberikan pengaruh dan untuk daerah kering air dan vegetasi mempengaruhi pertumbuhan sagu, sedangkan kelembaban dan cahaya tidak berpengaruh, hal ini dapat dilihat pada Tabel 1

Tabel 1. Hasil Uji Pengaruh Faktor Lingkungan Asal Seget

Jenis Sagu dan Koefisien $\mathrm{T}$ hitung $\mathrm{P}$ value $\mathrm{F}$ hitung $\mathrm{R}^{2}$

Variabel regresi (p)

1. Jenis Wafok

Konstanta

Porositas tanah

$\mathrm{pH}$ air

Kelembaban

Cahaya

Vegetasi

\begin{tabular}{|c|c|c|c|}
\hline$-15,994$ & $-0,861$ & 0,398 & \multirow[t]{6}{*}{9,049} \\
\hline 0,128 & 2,166 & 0,041 & \\
\hline 1,145 & 1,843 & 0,078 & \\
\hline 0,154 & 0,741 & 0,466 & \\
\hline 0,106 & 1,753 & 0,042 & \\
\hline$-0,099$ & $-1,540$ & 0,137 & \\
\hline
\end{tabular}

2. Jenis Wahnan

Konstanta
Porositas tanan

$\begin{array}{lll}-15,002 & -0,642 & 0,527\end{array}$

\begin{tabular}{llll}
$\mathrm{pH}$ air & 1,584 & 2,028 & 0,024 \\
\cline { 2 - 4 } & 9,082
\end{tabular}

\begin{tabular}{lccc}
\hline Kelembaban & 0,057 & 0,217 & 0,830 \\
\hline Cahaya & 0,123 & 1,620 & 0,118 \\
\hline Vegetasi & $-0,053$ & $-0,652$ & 0,520 \\
\cline { 2 - 3 } 3. Jenis Wamda & & &
\end{tabular}

3. Jenis Wamda

\begin{tabular}{|c|c|c|c|c|c|}
\hline \multirow{2}{*}{$\begin{array}{l}\text { Konstanta } \\
\text { Porositas tanah }\end{array}$} & $-0,913$ & $-0,079$ & 0,938 & \multirow{6}{*}{14,951} & \multirow{6}{*}{0,757} \\
\hline & 0,093 & 2,502 & 0,020 & & \\
\hline pH air & 1,347 & 3,473 & 0,002 & & \\
\hline Kelembaban & 0,025 & 0,190 & 0,851 & & \\
\hline Cahaya & 0,042 & 1,119 & 0,274 & & \\
\hline Vegetasi & $-0,052$ & $-1,284$ & 0,211 & & \\
\hline \multicolumn{6}{|l|}{ 4. Jenis Wirere } \\
\hline Konstanta & $-11,674$ & $-0,900$ & 0,377 & \multirow[b]{3}{*}{13,010} & \multirow{6}{*}{0,730} \\
\hline Porositas tanah & $\underline{0,090}$ & 2,178 & $\underline{0,039}$ & & \\
\hline pH air & 1,438 & 3,317 & 0,003 & & \\
\hline Kelembaban & 0,121 & 0,832 & 0,413 & \multirow[t]{3}{*}{$(0,000)$} & \\
\hline Cahaya & 0,055 & 1,318 & 0,200 & & \\
\hline Vegetasi & $-0,046$ & $-1,014$ & 0,321 & & \\
\hline
\end{tabular}

Untuk daerah kering air dan vegetasi mempengaruhi pertumbuhan sagu jenis wahnan, sedangkan kelembaban dan cahaya tidak mem- 
pengaruhi. Air, cahaya dan vegetasi mempengaruhi pertumbuhan jenis sagu wamda untuk daerah temporer dan kering, sedangkan kelembaban tidak mempengaruhi.

Tabel 2. Hasil Uji Pengaruh Faktor Lingkungan Sagu Asal Kainui

\begin{tabular}{|c|c|c|c|c|c|}
\hline $\begin{array}{l}\text { Jenis Sagu } \\
\text { dan Variabel }\end{array}$ & $\begin{array}{l}\text { Koefisien } \\
\text { regresi }\end{array}$ & T hitung $\mathrm{P}$ & value $\mathrm{F}$ & $\begin{array}{l}\text { hitung } \mathrm{R}^{2} \\
\text { (p) }\end{array}$ & \\
\hline Konstanta & 6,833 & 0,340 & 0,737 & \multirow{7}{*}{$\begin{array}{r}11,843 \\
(0,000)\end{array}$} & \multirow[t]{6}{*}{0,712} \\
\hline Porositas tanah & , 142 & 2,502 & ,020 & & \\
\hline $\mathrm{pH}$ air & 1,851 & 3,536 & ,002 & & \\
\hline Kelembaban &,- 094 &,- 447 & ,659 & & \\
\hline Cahaya &,- 070 & $-1,146$ & ,263 & & \\
\hline Vegetasi &,- 023 &,- 363 & ,720 & & \\
\hline \multicolumn{4}{|c|}{ 2. Jenis Anangbatang } & & \multirow{7}{*}{$0,65 \mathrm{c}$} \\
\hline Konstanta & $-13,087$ & $-0,502$ & 0,620 & \multirow{6}{*}{$\begin{array}{c}9,295 \\
(0,000)\end{array}$} & \\
\hline Porositas tanah & 0,169 & 2,305 & 0,030 & & \\
\hline $\mathrm{pH}$ air & 1,985 & 2,918 & 0,008 & & \\
\hline Kelembaban & 0,116 & 0,426 & 0,674 & & \\
\hline Cahaya & $-0,059$ & $-0,747$ & 0,462 & & \\
\hline Vegetasi & $-0,080$ & $-0,972$ & 0,341 & & \\
\hline \multicolumn{6}{|l|}{ 3. Jenis Kurai } \\
\hline Konstanta & $-10,837$ & $-0,428$ & 0,672 & \multirow{6}{*}{$\begin{array}{l}10,526 \\
(0,000)\end{array}$} & \multirow[t]{6}{*}{0,687} \\
\hline Porositas tanah & 0,187 & 2,626 & 0,015 & & \\
\hline $\mathrm{pH}$ air & 1,880 & 2,847 & 0,009 & & \\
\hline Kelembaban & 0,075 & 0,283 & 0,780 & & \\
\hline Cahaya & $-0,049$ & $-0,634$ & 0,532 & & \\
\hline Vegetasi & $-0,100$ & $-1,245$ & 0,225 & & \\
\hline
\end{tabular}

Berdasarkan Tabel 2 dijelaskan bahwa faktor yang mempengaruhi secara signifikan pertumbuhan sagu jenis Amiri di lokasi Kainuit daerah tergenang yaitu porositas tanah dan $\mathrm{pH}$ air $(\mathrm{p}<0,05)$, sedangkan kelembaban, cahaya dan vegetasi tidak $(p>0,05)$ sedangkan jenis Anangbatang di lokasi Kainui daerah tergenang yaitu porositas tanah dan $\mathrm{pH}$ air $(p<0,05)$, sedangkan kelembaban, cahaya dan jumlah vegetasi tidak ( $p>0,05)$.

Untuk lokasi Kainui air mempengaruhi pertumbuhan sagu jenis amiri, anangbatang dan kurai untuk daerah kering, temporer dan rawa sedangkan kelembaban, cahaya dan vegetasi tidak mempengaruhi pertumbuhan sagu tersebut. Air memegang peranan penting bagi pertumbuhan tanaman sagu. Air berfungsi sebagai sumber hara tanaman dan sebagai pelarut unsur hara. Pertumbuhan pohon sagu sangat tergantung pada ketersediaan hara esensial dan air yang ada dalam tanah. Kondisi air yang berlebihan seperti pada tempat tumbuh daerah rawa, tidak berguna bagi pertumbuhan karena mengakibatkan keadaan aerasi tanah yang buruk bagi akar tanaman. Aerasi tanah berhubungan erat dengan jumlah udara yang ada dalam tanah. Ketersediaan udara dalam tanah sendiri akan menentukan banyaknya $\mathrm{CO} 2$ yang dıbentuk darı nası perombakan banwa organık oleh jasad mikro. Air adalah salah satu komponen penting yang mempengaruhi pertumbuhan tanaman dimana pada saat kondisi cekaman air terjadi dan daun akan terlihan mengecil. Air merupakan penyusun tubuh daun yang berperan dalam proses metabolisme dan jika terjadi kekurangan air maka proses metabolisme yang terjadi akan lebih sedikit.

Auri (1992), menyatakan bahwa palma sagu tidak selamanya harus tergenang air, namun terdapat waktu-waktu tertentu dimana palma sagu kurang atau tidak membutuhkan air dalam jumlah banyak, misalnya pada saat menjelang panen.

Kelembaban udara relatif tidak berpengaruh untuk pertumbuhan jenis sagu Wafok,

Wahnan,Wamda dan Wirere di lokasi Seget dan jenis sagu Amiri, Anang Batang dan Kurai di

lokasi Kainui. Kelembaban udara relatif tidak berpengaruh disebabkan hasil yang diperoleh cukup

besar dan sesuai untuk pertumbuhan sagu, dapat terlihat pada lampiran 5 dan lampiran 10 yaitu ratarata kelembaban udara per tahun di desa Seget dan Kainui sebesar 85,33\% dan 83,60\% yang sama pada tempat tumbuh sagu yang kering, transisi dan rawa. Kelembaban udara relatif Seget dan Kainui menunjukan bahwa kandungan uap air dibawah tegakan sagu cukup besar. Kelembaban udararelatif lebih tinggi disebabkana karena pergerakan uap air di bawah tegakan sagu berjalan lambat karena tertutup tajuk sagu yang tumbuh sangat rapat.

Flach (1997) mengemukakan bahwa sagu membutuhkan kondisi kelembaban $>70 \%$ untuk menjamin pertumbuhannya yang lebih baik. Menurut Harsanto (1990), kelembaban udara lebih dari $60 \%$, maka sagu dapat tumbuh dengan baik, sedangkan pertumbuhan sagu akan terhambat bila 
kelembaban udara kurang dari $40 \%$. Hal ini sesuai dengan penelitian Samin etal. (2011) bahwa pertumbuhan sagu sesuai pada kelembaban udara relatif 87,97-91,60 \% dan penelitian Matanubun et al. (2005), tumbuhan sagu tumbuh baik pada kondisi kelembaban udara relatif sekitar 83,34\%.

Sinar matahari sangat dibutuhkan untuk proses pertumbuhan tanaman, Hasil analisis menunjukkan bahwa rata-rata lamanya penyinaran matahari pertahun di desa Seget dan desa Kainui sebesar 49,74 $\%$ dan 49,60\%. Banyak sedikitnya sinar matahari yang diterima tanaman akan mempengaruhi proses fotosintesa. Faktor yang mempengaruhi berkurangnya penangkapan sinar matahari adalah dari tanaman sagu yang rapat, sehingga menghalangi sinar matahari yang masuk untuk jenis. Faktor lain yang mempengaruhi berkurangnya penangkapan sinar matahari adalah tajuk vegetasi tanaman lain yang menutupi areal tempat tumbuh, perbedaan anatomis sagu di Seget dan Kainui pertumbuhan anakan, panjang pelepah, diameter serta tinggi tanaman yang berbeda - beda.

Prihastanti (2010), menyebutkan faktor penting yang berpengaruh terhadap proses pertumbuhan dan perkembangan tanaman adalah cahaya, dimana akan mempengaruhi proses pembuatan zat makanan pada saa fotosintesis. Cahaya selain mempengaruhi fotosintesis juga sangat dibutuhkan oleh tanaman dalam proses-proses metabolisme lainnya.

Vegetasi lain mempengaruhi pertumbuhan sagu sehingga hal ini menggambarkan tidak akan terjadi toleransi untuk hidup secara bersama atau tidak ada hubungan timbal balik yang saling menguntungkan, terutama dalam pembagian ruang hidup. Dalam suatu komunitas asosiasi yang bersifat negatif memberikan petunjuk pada setiap tumbuhan terjadi saling memberi tempat hidup pada suatu area dan habitat yang sama Barbour et al. (1999) dalam Kurniawan et al. 2008). Krivan dan Sirot (2002) yang menyatakan bahwa dalam asosiasi interspesifik dapat memunculkan kompetisi interspesifik, dimana asosiasi bersifat negatif ekstrim, suatu spesies dapat muncul sebagai kompetitor yang mendominasi spesies lain.

Suhu udara, curah hujan dan keadaan kimia tanah juga mempengaruhi pertumbuhan tanaman jenis sagu yang ada di lokasi Seget dan Kainui selain air, cahaya, kelembaban dan vegetasi . Suhu udara untuk lokasi Seget adalah $23,44^{\circ} \mathrm{C}-31,14^{\circ} \mathrm{C}$ dan Kainui adalah dari $22,5^{\circ} \mathrm{C}-31,14^{\circ} \mathrm{C}$. Suhu merupakan faktor lingkungan yang berpengaruh terhadap pertumbuhan dan perkembangan tanaman. Suhu berkorelasi positif dengan radiasi matahari. Tinggi rendahnya suhu disekitar tanaman ditentukan oleh radiasi matahari, kerapatan tanaman, distribusi cahaya dalam tajuk tanaman, dan kandungan lengas tanah. Hasil yang diperoleh menunjukan suhu di kedua lokasi hampir sama dengan data suhu dari penelitian Samin (2011), yaitu berkisar antara22,69 $-23,94^{\circ} \mathrm{C}$. Suhu udara yang diperoleh rendah akibat tajuk tanaman sagu yang menutupi cahaya sehingga tidak dapat menembus lantai hutan sagu sehingga suhu udara menjadi berkurang. Hasil yang diperoleh juga hampir sama nilainya dengan Matanubun et al (2005).

Curah hujan di Seget dan Kainui rata-rata tiap tahun sekitar 3118,4 mm dan 3545,75 mm, jumlah ini sesuai dengan pendapat Harsanto (1986) yang menyatakan jumlah hujan yang menguntungkan bagi pertumbuhan sagu diduga antara $2000 \mathrm{~mm}$ - $4000 \mathrm{~mm}$ per tahun. Sifat fisik tanah yang diduga berpengaruh adalah drainase dan aerasi tanah. Harsanto (1985) menyatakan bahwa tempat tumbuh yang baik bagi sagu pada tanah yang tidak tergenang air sehingga akar napas tidak terendam. Tempat tumbuh demikian tidak ditemui di daerah rawa dan transisi. Lokasi penelitian Seget dan Kainui merupakan bahwa daerah kering memiliki drainase yang baik, daerah temporer jelek dan daerah rawa sangat jelek. Kondisi drainase yang jelek dihambat oleh permukaan air tanah yang tinggi, mengakibatkan ruang pori tanah seluruhnya terisi air.

Derajat kemasaman $(\mathrm{pH})$ tanah di Seget dan Kainui tergolong sangat masam, dimana $\mathrm{pH}$ tanah demikian memiliki reaksi tanah yang cocok untuk pertumbuhan sagu (Flach,1983). Namun demikian pada daerah rawa dan daerah temporer yang memiliki air tanah berlebihan terdapat persaingan penggunaan oksigen antara pohon sagu dengan jasad renik. Pada keadaan air tanah yang berlebihan beberapa unsur hara seperti nitrogen, sulfur, ferrum dan mangan akan diredusikan. Unsur nitrogen dan sulfur akan hilang menguap ke udara, unsur ferrum 
mangan dalam keadaan reduksi akan larut dalam air tanah sehingga dapat mencapai tingkat keracunan (Kartasapoetra, 1991).

Daerah temporer pada lokasi pengamatan memiliki kadar karbon tergolong sangat tinggi, daerah rawa tergolong tinggi dan daerah kering tergolong sedang. Keadaan kadar karbon tersebut didukung oleh pernyataan yang dikemukakan oleh Fitter dan Hay (1992) yang menyatakan bahwa sifat tidak mendukung dari tanah tergenang pada daerah temporer dan daerah rawa adalah konsentrasi karbon yang tinggi dan keadaan oksigen yang rendah, sehingga mengakibatkan terhambatnya perkembangan dan penyebaran akar di dalam tanah.

Daerah kering pada lokasi pengamatan memiliki kadar nitrogen tergolong sangat rendah, daerah rawa tergolong rendah dan daerah temporer tergolong tinggi. Namun dengan adanya keadaan tanah yang tergenang, drainase yang buruk dan tata udara yang jelek pada daerah transisi dan daerah rawa menyebabkan terciptanya situasi anaerobik sehingga organisme tanah akan menggunakan nitrat dan mereduksinya menjadi gas nitrogen, nitrogen berubah bentuk menjadi tidak tersedia bagi tumbuhan (Hardjowigeno, 1992).

Daerah kering pada lokasi penelitian memiliki rasio karbon/nitrogen tergolong sangat tinggi, sedangkan daerah rawa dan daerah transisi tergolong tinggi. Bila terdapat rasio karbon/nitrogen sangat tinggi maka pada daerah tersebut banyak terdapat serasah daun segar pada permukaan tanah, sehingga bahan ini sedang dioksidasi organisme tanah berkembang berlipat ganda. Pohon sagu harus menunggu pembebasan nitrogen oleh organisme ini bila jumlahnya telah berkurang dengan rendahnya rasio karbon/nitrogen (Theodore $d k k, 1987$ ).

Proses dekomposisi serasah daun segar pada permukaan tanah sangat dipengaruhi oleh suhu, kelembaban dan aerasi tanah. Daerah kering pada lokasi Seget maupun Kainui memiliki keadaan tanah yang lembab dan aerase tanah relatif baik, sehingga proses dekomposisi serasah daun segar berlangsung cepat, sedangkan pada daerah rawa dan temporer yang memiliki air yang buruk memiliki proses lambat. Menurut Theodore $d k k$ (1987) pada daerah rawa dan transisi (selalu tergenang), proses dekomposisi berjalan lambat sehingga ion hidrogen akan menggantikan kation-kation lain seperti kalsium, magnesium, kation rendah dan kejenuhan basa menjadi meningkat. Akibat lanjutnya adalah pada daerah tersebut hanya tersedia sedikit kation hara yang diperlukan untuk pertumbuhan dan anion hara seperti ion fosfat, sulfat dan nitrat lepas atau akan terikat dalam bentuk yang tak tersedia. Apabila unsur-unsur hara essensial tersebut terus-menerus berkurang maka dapat mengakibatkan terhambatnya pertumbuhan pohon sagu.

Daerah temporer dan daerah rawa di lokasi Seget maupun Kainui memiliki kadar phosphat tergolong rendah, sedangkan daerah kering tergolong sangat rendah. Namun daerah rawa dan transisi yang tergenang di lokasi pengamatan mengakibatkan ion ferro $\left(\mathrm{Fe}^{2+}\right)$ yang dapat larut dioksidasi menjadi ion ferri $\left(\mathrm{Fe}^{3+}\right)$ yang tidak dapat larut. Ion ferri tersebut dan ion kalsium akan mengikat unsur phosfor yang tersedia di dalam tanah, sehingga tidak dapat digunakan oleh pohon sagu (Hardjowigeno, 1992) (Sanchez, 1993).

Daerah kering daerah temporer di Seget dan Kainui memiliki kapasitas tukarkation (KTK) yang tinggi dan daerah rawa sedang. Kapasitas Tukar Kation merupakan sifat kimia yang sangat erat hubungannya dengan kesuburan tanah. Tanah dengan KTK yang tinggi pada daerah kering dan temporer menunjukan bahwa pada kedua tempat tumbuh tersebut mampu menyediakn unsur hara yang lebih baik dibandingkan dengan tanah pada daerah rawa. Berhubung unsur-unsur hara berada dalam kompleks jerapan koloid, maka unsur-unsur hara yang terserap tersebut tidak mudah tercuci oleh air.

Susunan kation pada daerah kering di Seget dan kainui yaitu mengandung unsur kalium, natrium dan kalsium yang tergolong rendah dan unsur magnesium yang tergolong tinggi. Daerah temporer memiliki unsur kalium dan kalsium tergolong rendah, unsur natrium yang tergolong sedang dan unsur magnesium yang tergolong tinggi. Daerah temporer dan daerah rawa yang memiliki kondisi tanah yang tergenang dapat mempercepat penguraian senyawa padat dari unsur-unsur ini. Jumlah yang besar dari ion $\mathrm{NH}^{4+}, \mathrm{Fe}^{2+}$ dan $\mathrm{Mn}^{2+}$ yang 
dibebaskan pada penggenangan dapat memindahka sejumlah besar kalsium, magnesium dan kalium dari tempat yang dipertukarkan ke dalam larutan tanah. Akibatnya semua ion itu menjadi lebih mudah mengalami pencucian. Dilain pihak, air genangan yang permanen biasanya membawa basa dapat dipertukarkan itu dalam jumlah yang banyak. Keadaan ini dapat dilihat pada kondisi kejenuhan basanya. Pada daerah rawa memiliki kejenuhan basa tergolong sedang, pada daerah kering dan transisi tergolong rendah (Sanchez, 1993).

Haryanto dan Pangloli (1992), menyatakan tempat tumbuh yang dapat menunjang pertumbuhan sagu adalah pada tanah-tanah yang mengandung banyak mineral dan bahan organik, daerah berair tawar tetapi akar-akar pohon sagu tidak terendam air serta tidak sering dipengaruhi oleh air pasang surut. Kriteria keadaan tempat tumbuh yang demikian ditemui hanya pada daerah kering sehingga dapat menunjang pertumbuhan sagu.

Daerah temporer dan daerah rawa memiliki kondisi air tanah yang berlebihan apabila dibandingkan daerah kering. Keadaan air tanah yang berlebihan menyebabkan proses gerakan masa air dari dalam tanah menuju permukaan akar pohon berlangsung terus menerus. Air yang diserap oleh akar pohon digunakan untuk proses transpirasi dan respirasi, dimana sebagian air tersimpan dalam batang pohon akibat kelenturan sel xylem. Ketika transpirasi berkurang pada malam hari atau pada saat hujan, tegangan dalam xylem mengendur namun air terus diserap akar pohon hingga tegangan berkurang. Apabila tempat tumbuh selalu berair, maka pohon sagu yang tumbuh tempat tersebut akan mengandung lebih banyak air di dalam batang seperti halnya pada pohon tebu (Adisewejo, 1991).

\section{KESIMPULAN}

1. Hubungan pertumbuhan sagu dengan faktor lingkungan edafik (air), klimatik (kelembapan, cahaya), dan biotik (vegetasi) menunjukan bahwa secara umum air berpengaruh terhadap pertumbuhan sagu faktor kelembaban terhadap semua tipe tempat tumbuh yakni pada daerah tergenang, daerah temporer dan daerah kering tidak mempengaruhi pertumbuhan sagu.

2. Pertumbuhan tanaman sagu di daerah Kainu dan Seget sangat dipengaruhi oleh air berfungsi sebagai sumber hara tanaman dan sebagai pelarut unsur hara, dimana Pertumbuhan pohon sagu sangat tergantung pada ketersediaan hara esensial dan air yang ada dalam tanah.

\section{DAFTAR PUSTAKA}

Anonim. 1976. Mengenal Jenis-Jenis Kayu di Papua. Dinas Kehutanan Propinsi Dati I. Papua.

Adisewejo. R.S. 1991. Bercocok Tanam Tebu (Sacharum officinum). Bale Bandung, Bandung.

Auri, J. P. 1991. Keadaan Hutan Sagu Di Irian Jaya. Makalah Seminar Pengembangan Sumberdaya Sagu Di Irian Jaya, Manokwari 10 -11 Desember.

Barahima. 2006. Keragaman Genetik Sagu di Indonesia berdasarkan Penanda Molekuler Genom Kloroplas dan Genom Inti (disertasi). Bogor. Sekolah Pascasarjana, Institut Pertanian Bogor.

Fitter. A. H dan R. K. M. Hay 1992. Fisiologi Lingkungan Tanaman. Gadjah Mada University Press. Yogyakarta.

Flach, M. 1983. The Sago Palm : Domestication, Exploitation and Product. Preprint. FAO Plant Production and Protection. Rome. 85p.

Flach, M. 1977. The Sago Palm and its Yield Potential. First Internaasional Sago Symposium in Serawak. Univ. of Malaya Press - Kuala Lumpur.

Hardjowigeno, S. 1987. Ilmu Tanah Meltron Putra. Jakarta

Harsanto, P. B. 1986. Budidaya Dan Pengolahan Sagu. Penerbit Kanisius, Yogyakarta.

Haryanto dan Pangloli. 1992. Potensi dan Pemanfaatan Sagu. Penerbit Kanisius, Yogyakarta,140p.

Kartasapoetra. G., A. G. Kartasapoetra dan M. M. Sutedjo 1987. Teknologi Konservasi Tanah dan Air. Meltron Putra, Jakarta. 
Krivan V and Sirot E. 2002. Habitat Selection by to Competing Species in a Two Habitat Environment. J The American Naturalist 160 (2) : $214-234$

Kurniawan A, Undaharta Ni KE, Pendit I Made R. 2008. Asosiasi Jenis-Jenis Pohon Dominan di Hutan Dataran Rendah Cagar Alam Tangkoko, Bitung, Sulawesi Utara. J Biodiversitas 8 (3) : 199-203.

Manan, S., S. Soepangkat, Y.Abas, dan S. Sukandar. 1984. Conservation Program on Sago Palm in Indonesia. Paper Presented at The Expert Consultation in the Development of the Sago Palm and Palm Products, Jakarta , Januari 16 $-21,1984$.

Matanubun $\mathrm{H}$ et al. 2005. Feasibility study of the natural sago forest for the establishment of the commercial sago palm plantation at Kaureh District, Jayapura, Papua Province Indonesia. (Edt. Yan P. Karafir, Foh. S. Jong, and Cictor E. Fere). Proceeding of the eighth International sago symposium, Jayapura, August 4-6, 2005.
Prihastanti, E. 2010 .Perkecambahan Biji dan Pertumbuhan Semai Tanaman Jarak Pagar. Anatomi dan Fisiologi, 8(1) : 49-56.

Samin Botanri, Dede Setiadi, Edi Guhardja, Ibnul Qayim,dan Lilik B. Prasetyo. 2011. KarakteristikHabitat Tumbuhan Sagu (Metroxylon spp.) Di Pulau Seram, Maluku.

Suryani, C. L. dan Haryadi. 1998. Pemutihan dan Pengikatan Silang Pati Sagu dan Penggunaannya untuk Bahan Substitusi pada Pembuatan Bihun. Agritech 18: 20-23.

Sanchez, P. A. 1993. Sifat-Sifat dan Pengelolaan Tanah Tropika. ITB Bandung. Bandung.

Theodore. W. D, J. A. Helms dan F. S. Baker. 1987. Prinsip-prinsip Silvikultur. Gadjah Mada University Press. Yogyakarta. 